\title{
WAR, THE NATION, AND THE KINGDOM OF GOD: THE ORIGINS OF THE NATIONAL MISSION OF REPENTANCE AND HOPE, 1915-16
}

by DAVID M. THOMPSON

THE NATIONAL Mission of Repentance and Hope, launched by the archbishops of Canterbury and York and L led by the bishop of London in the autumn of 1916, has not been regarded as one of the more successful episodes in the history of the Church of England. Hensley Henson, who can always be relied upon for a suitable comment, called it 'a grave, practical blunder', whilst a very different type of churchman, Conrad Noel, called it 'the Mission of Funk and Despair'. ${ }^{1}$ Its treatment in the secondary sources is curious. Bell has a chapter on it in his life of Randall Davidson, but it says much about Davidson and little about the Mission. The same is true, mutatis mutandis, of Iremonger's treatment in the life of Temple. S. C. Carpenter chose to omit the chapter on the National Mission from his life of Winnington-Ingram. Lloyd depends heavily on Bell; Wilkinson is more rounded, but the fullest account by Mews remains unpublished. ${ }^{2}$

In the past attention has been concentrated on what seemed to flow from the National Mission-the life and liberty movement, perhaps, or the reports of the archbishops' committees of inquiry, especially the fifth report on 'Christianity and Industrial Problems'. Temple was much involved in both of these developments, and closer investigation suggests that Temple used the Mission as a lever to push forward these ideas. In other words, the

1 [E. F.] Braley, Letters [of Herbert Hensley Henson] (London 1950) p 14; R. Groves, Conrad Noel and the Thaxted Movement (London 1967) p 176.

2 [G. K. A.] Bell, [Randall] Davidson 3rd ed (London 1952) pp 767-74; [F. A.] Iremonger, [William] Temple (London 1948) pp 204-19; S. C. Carpenter, Winnington-Ingram (London 1949) p 4; [R.] Lloyd, [The] Church of England [1900-1965] (London 1966) pp 226-31;

[A.] Wilkinson, [The] Church of England and [the First World] War (London 1978) pp 70-9; S. P. Mews, Religion and Society in England in the First World War (unpub. Cambridge Ph.D. dissertation 1974) pp 224-301. 
Mission may more properly be regarded as the occasion, rather than the cause, of these initiatives. A study of the origins of the National Mission, however, illuminates the response of the Church of England to the first world war, particularly when it began to go badly. The changes between what was originally proposed and what eventually happened also indicate the differing appraisals of the contemporary situation that existed within the church.

There was no single source for the idea of a National Mission. When the archbishop of Canterbury first made his proposal public in November 1915, the Record claimed that the first suggestion of a national mission had been made in a letter from ' $F$ ' twelve months earlier, whilst the Church Family Newspaper recalled that it had urged the need for 'a great National Mission in all parishes of the land' in January 1915. ${ }^{3}$ The concept of a simultaneous mission shared by these two evangelical newspapers, however, was precisely that which Davidson and his advisers did not intend. William Temple wrote that

A group of laymen who met together two or three times in the late spring and early summer of 1915 became convinced that though there were few open signs, yet under the surface there was a very deep stirring, though they were puzzled and distressed that, on the whole, the nation seemed so little alive spiritually. ${ }^{4}$

This group wrote to Davidson, who showed little enthusiasm for their proposal of some special effort: but when they persisted, he promised to take some preliminary steps. ${ }^{5}$ The group was probably that responsible for the Laymen's Christian Crusade, with whose secretary, A. P. Charles, Temple kept in touch throughout the summer of 1915. The concern of this group may well be represented by an article by Viscount Bryce in the Layman's Bulletin for June 1915, entitled 'The Immediate Duty of Christian Men', which concluded with these words:

Must we not make another effort to bring the individual life and the social life and the business life and the national life

3 Record 18 Nov 1915, referring to a letter in the issue for 8 Dec 1914; Church Family Newspaper 12 Nov 1915.

4 [W.] Temple; $A$ Challenge [to the Church] (London 1917) p 1.

5 Iremonger, Temple pp 206-7. This is not mentioned by Bell and I have been unable to trace this correspondence in the Davidson papers so far. 


\section{War, the Nation, and the Kingdom of God}

nearer to those Christian ideals in following which, as we believe, the best hopes for the peace and welfare of humanity are to be found?

Meanwhile in March 1915 Yeatman-Biggs, bishop of Worcester, wrote to Davidson expressing his concern that the spiritual opportunities of the war, which he had referred to in a letter to the Times, should be seized. Davidson replied in April saying that, after consulting Lang, archbishop of York, he would like to appoint a small group to think about it. In late May or June he began to discuss possible names with Dr A. W. Robinson, Warden of the College of Mission Clergy at All Hallows Barking by the Tower. On 24 July 1915 Davidson invited Robinson to gather the group together. ${ }^{7}$ The group consisted of E. A. Burroughs, chaplain of Hertford College, Oxford; B. K. Cunningham, Warden of Bishop's Hostel, Farnham; W. H. Frere, of Mirfield; Peter Green, of Manchester; Archdeacon E. E. Holmes, of St Paul's Cathedral; Canon G. C. Joyce, of Hawarden; J. G. McCormick, of St Michael's Chester Square; A. W. Robinson, of All Hallows; Canon V. F. Storr, of Winchester; and William Temple, of St James, Piccadilly. To these were added J. O. F. Murray, Master of Selwyn College, Cambridge and W. B. Trevelyan, of Beaconsfield. ${ }^{8}$ It is not known why Davidson chose Arthur Robinson for this task. His younger brother, Armitage Robinson, Dean of Wells, was well known to Davidson, who had worked with him on various liturgical matters and had asked him, among others, to prepare prayers at the outbreak of war. ${ }^{9}$ Robinson's work as Warden of the College of Mission Clergy had involved him in leading numerous missions, retreats and quiet days; and as chaplain of the London Diocesan Lay Helpers' Association he was in touch with a large number of the

- Viscount Bryce, 'The Immediate Duty of Christian Men' Layman's Bulletin June 1915: in the A. W. Robinson papers.

7 [Lambeth Palace Library], D[avidson] P[apers]: 'War' Box 14: bishop of Worcester to Davidson, 9 Mar 1915; Davidson to bishop of Worcester, 19 Apr 1915; A. W. Robinson to Davidson, 19 Jun 1915; Davidson to Robinson, 24 Jul 1915.

B Gore was not a member of the group, as stated by Wilkinson, Church of England and War $\mathrm{p} 72$.

- Bell, Davidson p 736. Armitage married Mrs Davidson's secretary in Lambeth Palace chapel in Jan 1915. Lloyd, Church of England $\mathrm{p} 226$, mistakenly says Armitage Robinson was asked to be chairman. H. E. Sheen, Canon Peter Green (London 1965) p 80 makes the same mistake. 
laity involved in church work. In November 1914 Davidson had asked him to prepare a homily which could be used in connection with the Day of Intercession planned for Sunday 3 January 1915, the prayers for which were being prepared by his brother. His work was widely appreciated, particularly for his ability to cross the party divisions in the church. ${ }^{10}$

Robinson agreed to the archbishop's request, and on 29 July Davidson invited those nominated to take part in

the consideration of ways in which we can effectively "buy up the opportunity' which the War affords and by the help of God bring good out of its manifold evil. We want thought to be given to our sins and shortcomings and to the best mode of overcoming them; we want fresh modes of prayerfulness, both public and private: and there are many other things in which a little spiritual counsel on the part of capable men would be, we believe, abundantly fruitful of good. ${ }^{11}$

All those invited accepted, and Robinson suggested that they should each set aside the hour between noon and $1.00 \mathrm{pm}$ on Mondays for special prayer, with a view to holding a conference of one or two days later on. ${ }^{12}$ The initial emphasis on prayer and spiritual devotion is therefore clear.

The group met for conference at The Yews, Beaconsfield from 4 to 6 October 1915. Frere and Green were absent, but had sent letters. After a wide-ranging discussion Robinson drafted a report for the archbishop, which commented on the current situation and made various proposals for greater freedom in worship. The key sentence was as follows:

We are unanimous in recommending that before the inevitable reaction sets in, which will follow the War, there should be a National Mission led by the Archbishops; that it should be on a scale such as we have never yet contemplated, and should extend throughout all the cities and towns and villages of the land. ${ }^{13}$

10 A. W. Robinson, The Way to Pray (London 1931) pp 23-7.

" [A. W.] R[obinson] P[apers]: circular letter from Davidson, 29 Jul 1915. I am grateful to the Rt Revd Dr J. A. T. Robinson, Trinity College, Cambridge, for allowing me to consult his father's papers, which are in his possession.

12 RP: circular letter of A. W. Robinson, Aug 1915.

13 RP: The Spiritual Call [to the Nation and the Church: What is being taught by the War and What should be done] (privately printed) p 6. 


\section{War, the Nation, and the Kingdom of God}

The report was considered by the bishops on 26 October, and Davidson made the first public mention of the idea in a letter to the Times published on 8 November, in which the second part of the sentence quoted above was included. Discussion of the idea in the church press then began.

On 24 November a meeting was held under the chairmanship of the bishop of London betwen members of the group and the bishops of Oxford, Salisbury, St Asaph and Chelmsford. Frere, Joyce and Storr were unable to attend. It was this meeting at which 'the determined pessimism' of Green and Gore became apparent. ${ }^{14}$ Some thought the church should undertake 'a definite extensive movement . . . which might be described as a National Mission', whilst others thought that the church was not spiritually ready for such an appeal and needed a considerable time of preparation. Perhaps surprisingly the meeting agreed, with only Gore abstaining,

1. THAT the present emergency demands some special action on the part of the Church to bring home to the Nation the call of God in the War, viz:

a. To realise its responsibility before God:

b. To recognise the duty of preparing afresh to serve the Kingdom of Christ throughout the world; and to this end

c. To put out of its own life the things that are contrary to righteousness and that make brotherhood impossible.

2. THAT as a preliminary to this action efforts should be made to rouse the Church
a. To realise the greatness of its opportunity to proclaim Christ crucified, risen, and ascended as the present Lord of Life;
b. To seek to be filled anew with the power of the Holy Spirit; and to this end
c. To be forward in putting away from every department of its life all that can hinder fellowship, and make worship and witness unreal. ${ }^{15}$

14 Bell, Davidson pp 767-8; Robinson to Davidson, 24 Nov 1915.

15 RP: [Informal] report of a Conference [held at London House on] November 24, typescript, pp 2, 35-6. 
The decision on the next step was left to the archbishop of Canterbury. Notwithstanding the hesitations expressed by many about the title, 'National Mission', he decided to proceed on that basis. In January 1916 he invited seventy people to form a central council for the mission, modelled on the organisation for the PanAnglican Congress of 1908. The bishops agreed to his plans on 2728 January, and the first meeting of the Council took place on 14 February, when the Mission was arranged for OctoberNovember 1916. On 15 February Davidson announced the proposal at the Convocation of Canterbury, and Lang told the Convocation of York the following day. ${ }^{16}$ Winnington-Ingram, bishop of London, became, in his own words, 'chief of the staff of the National Mission'-a post which the original group had conceived as "analagous to that of the "Minister of Munitions" '.17 Though he threw himself heart and soul into the task, his vision of the National Mission was different from the original one, and Temple may not have been too unkind when he commented acidly that 'Ebor, London, and a good lot more just want a few mass meetings in the Albert Hall. '18 More calmly later he said that after the Council's retreat at Westfield College, London, 28-30 March 1916, 'there was on the Council a perfect unity of spirit', though differences of opinion still remained. ${ }^{19}$

Before turning in more detail to the ideas behind the Mission it is worth noting that the months during which it was planned saw a significant change in the public mood about the war. Attempts to break the military stalemate on the western front ended in midOctober, but the alternative to that front collapsed when troops were evacuated from the Dardanelles in December. On 5 October, during the meeting at Beaconsfield, Lord Derby was appointed to take charge of the last major voluntary recruitment drive with a six-weeks time limit. On 5 January 1916 the Military Conscription Bill was introduced in the House of Commons. For those who favoured conscription this was the climax of a campaign to assert that the nation had the right to demand the lives of its citizens in a national emergency. It marked a radical break with British tradition: it also posed problems for the church

16 The Chronicle of Convocation, $1916 \mathrm{pp}$ 3-8; The York Joumal of Convocation, 1915-16 pp 95-98.

17 The Chronicle of Convocation, 1916 p 52; The Spiritual Call $\mathrm{p} 6$.

18 Iremonger, Temple p 208.

19 Temple, 4 Challenge $\mathrm{p} 3$. 


\section{War, the Nation, and the Kingdom of God}

because of the question of whether clergy should be exempt. This developing public emphasis on service and commitment may also have assisted the movement away from the more spiritual concerns of August-October 1915.

Much of the discussion at Beaconsfield was taken up with the failure of the clergy to provide for the spiritual needs of the nation. Frere was particularly critical: 'we have allowed ourselves to be paralysed by a prevailing spirit of Cathedral mattins which makes very little demand on anybody but the choir'. ${ }^{20}$ In a later letter he wrote:

Prayer for the dead is one of our greatest levers \& our neglect of it one of our worst faults. Our neglect of the H. Euch. comes in the same category: we are starved \& dumb, particularly in face of death. While of preaching we have already too much \& for lack of the prayer it runs to waste..$^{21}$ But Frere was not a lone voice: a very different kind of churchman, Francis Storr said that the clergy did not know how to visit or how far to lead in prayer, and that they had failed in 'memorial' services of all kinds. ${ }^{22}$ The group wanted to see greater freedom in church services, more open prayer-meetings, eucharists arranged 'at an hour at which the largest number of communicants can be expected'. They also recommended that the clergy

should call their people to prayer from the pulpit, giving them help in the offering of prayer, but not confining themselves to the reading of set collects. It might be ordered that the Churches should be opened for some hours every day for private prayer, and that in every Church there should be at least one special service of Intercession during the week. ${ }^{23}$ The suggestion was also made that churches in a deanery might arrange a rota of continuous intercession, by leagues of prayer and such like-though Davidson himself was dubious about this idea. ${ }^{24}$ The emphasis in Robinson's correspondence about the need for

20 RP: Frere to Robinson, 30 Sept 1915.

21 RP: Frere to Robinson, 21 Oct 1915.

22 RP: Robinson's ms notes of Beaconsfield meeting, October 1915. Except where otherwise indicated statements made at this meeting come from this source, which is unpaginated.

${ }^{23}$ The Spiritual Call pp 6, 8.

24 DP: 'National Mission' Box 1: Davidson to Mrs Penrose, 23 Jun 1915; Davidson to Robinson, 6 Aug 1915. 
appropriate biddings after the third collect or before the sermon suggests that it was widely felt that the clergy were liturgically unimaginative or unadventurous. Does this mean therefore that the first world war is the point from which a more spontaneous and less book-bound approach to worship in the Church of England is to be found? It is certainly a reminder that the forces behind prayer-book revision in the 1920 s were not solely anglocatholic. Perhaps the widespread custom of leaving Anglican parish churches open on weekdays dates from the war too.

But the group at Beaconsfield felt that the war had done more than expose the spiritual inadequacies of the Church of England. They interpreted the war as part of God's purpose in history and his purpose for the nation. In his opening remarks Temple asserted the divine character of the nation, appointed by God for a purpose, and said that 'our nation must be made a province in Christ's Kingdom'. The theme is more fully expounded in his Bishop Paddock lectures in New York given early in 1915 and subsequently published as Church and Nation. 'The nation as well as the Church is a divine creation', he wrote: 'the world is by divine appointment a world of nations, and it is such a world that is to become the Kingdom of God'. ${ }^{25}$ Such an understanding drew on the critical study of the old testament, and the ideas of Maurice and Westcott. For this reason Storr said at Beaconsfield that the old testament ought to 'live' after this war. The old testament, however, also taught the need of repentance: in his account of the National Mission Temple wrote:

In 1914 God called us, as a nation, and we heard and obeyed His call . . . But though we answered God's call, it cannot be said that we answered it as His. It was the call of right, but we did not find in it the claim of God upon our lives, for we had grown unaccustomed to relate our religion to the national life. ${ }^{26}$

Corporate repentance was therefore necessary. E. S. Talbot, bishop of Winchester, also drew an old testament analogy to explain the Mission at the meeting with nonconformist representatives at Lambeth in July 1916:

${ }^{25}$ W. Temple, 'Our Need of a Catholic Church' Papers for War Time 2nd series, no 19 (London 1915) p 14; Church and Nation (London 1916) pp 44-5.

26 Temple, $A$ Challenge $\mathrm{p} 12$. 


\section{War, the Nation, and the Kingdom of God}

When the Assyrians came in the land Isaiah called on the nation to think of their sins. It was in this prophetic spirit that the Mission gave its call to repentance. ${ }^{27}$

The group were prepared to go further in their appraisal of the positive benefits of the war. Despite the ambivalent evidence of the state of religion on the western front, they looked deeper. Presenting their report to the meeting at London House in November 1915, Robinson summed up their thinking as follows:

Briefly these thoughts were that the chastisement of the War was a preparation of the nation by discipline to fulfil some great task, that the heroism and self sacrifice which had been revealed showed that the Nation had the latent spiritual power to accomplish that task, that the idea of the Nation as a corporate body which was uniting all men today made it seem that men would be more ready than ever before for the message of the Kingdom of God, and that the opportunity before the Church ought to be bought up before the inevitable reaction should set in after the War. ${ }^{28}$

Hence they believed there was 'an almost universal desire . . . for more peremptory leadership', what Temple called 'the almost passionate hunger for orders' ${ }^{29}$ McCormick was worried that the archbishop would not see how much they felt 'that something drastic \& even dramatic is wanted in the way of leadership'. ${ }^{30}$ Only Cunningham expressed some reservations about how widespread this desire was. ${ }^{31}$ The group therefore looked for a call to service which would draw on the kind of heroism manifested in the war. Temple wrote:

Men at present do think that the Church exists for the sake of its own members; consequently they are not attracted to it; when they feel that it exists, like the Army and Navy, for an end beyond its own members, and to which its members may have to be completely sacrificed, they will come in; and this is the original idea of the Church cf. Mark 8 v 34; Matthew 28 v $19 .{ }^{32}$

\footnotetext{
27 DP: 'National Mission' Box 1: Notes of [Private] Conference [at Lambeth], 21 July 1916.

2B RP: Report of a Conference, November 24, pp 1-2.

29 The Spiritual Call p 4; RP: Temple to Robinson, 22 Oct 1915.

30 RP: McCormick to Robinson, 20 Oct 1915.

31 RP: Cunningham to Robinson, 20 Oct 1915.

32 RP: Temple to Robinson, 22 Oct 1915.
} 
This letter was written as the Derby scheme for voluntary enlistment was getting under way, and its general tone is illuminating.

For Temple this linked easily with his view that all national sins were rooted in one fundamental one- 'the fact that we do not feel in any effective sense members one of another'. He pointed out that at the outbreak of war the country was on the brink of civil war in Ireland and the greatest labour war in history. ${ }^{33}$ Members of the group were well aware of the fragile state of domestic politics. Murray wrote that

The War found us with a mass of unsolved problems in an acute state $\&$ there are clear signs that the mere lapse of time is not reducing the tension. There can be no doubt that we are in for a period of serious domestic trouble as soon as the War is over, unless the whole of our social and political life can be raised to a higher plane. ${ }^{34}$

It is not difficult to understand therefore why members of the group like Temple felt it natural and right that the church should cooperate with other groups, like the labour movement, the women's movement, the temperance movement, the purity movement and so on, as part of this campaign. Involvement in social issues for them was not an extra added on to an evangelistic campaign: but it is doubtful whether Davidson ever fully understood this, and Winnington-Ingr am certainly did not see it in the way Temple did, though he had his own interest in temperance and purity. These are important clues as to why the concept of the National Mission was vague, not helped by the fact that all agreed it was a misleading title but they could not think of a better one.

The different conceptions of the National Mission also affected the decision over its timing. The group which met at Beaconsfield were quite clear that the Mission should take place immediately after the war, before 'the inevitable reaction' set in. Davidson's immediate response was that they 'should avoid talking too glibly \& easily about what we are going to do when the War is over' ${ }^{35} \mathrm{At}$ the November meeting at London House, as has already been stated, opinion was divided between those who thought there should be a Mission and those who thought the church was not

33 Temple, $A$ Challenge $\mathrm{p} 15$.

34 RP: Murray to Robinson, 8 Oct 1915.

35 RP: Davidson to Robinson, 8 Oct 1915. 


\section{War, the Nation, and the Kingdom of God}

ready for it. It was also felt by many that those who ought to lead such a Mission were either away at the front or stretched to the limit at home. Lang felt strongly that the Mission ought to precede not follow the end of the war. ${ }^{36}$ Eventually the bishops in January agreed to this policy. In effect they decided to use the name 'National Mission' for what many of the original group had regarded as the preparation for the Mission. This decisionperhaps a typical Davidson way of getting round a problem-was probably responsible for the fatal confusion over the Mission's purpose. Temple wrote to Davidson that 'on first hearing of the date I did not grasp how much it would affect the scheme of the Mission as I had myself contemplated it'. ${ }^{37}$ Even Lang complained to Davidson after the first Council meeting that WinningtonIngram seemed more concerned to get a decision on OctoberNovember as the dates for the Mission than on the right ways to prepare for it. As it was, of course, because the National Mission was held in 1916, the idea of an effort after the war was gradually forgotten, unless perhaps COPEC can be seen in this light.

Another way in which the view of the Mission changed, though here more quickly, was over the question of cooperation with nonconformists. At Beaconsfield Burroughs spoke of a revival of united religion, and noted that much was now being done that was complained of at Kikuyu, the controversial missionary conference of 1913. Gilbert Joyce's notes of proposals at the end of the meeting included this one:

A religious War council to be summoned by the Archbishop \& to consist of Roman Catholics \& Nonconformists as well as Churchpeople. This would be purely an emergency organisation to meet an emergency. ${ }^{38}$

Robinson, however, envisaged the archbishop telling the nonconformists what the Church of England was going to do. Other members of the group were much more hesitant about cooperation: Trevelyan felt that they had not sufficiently emphasised their protest against the 'bugbear of undenominationalism'. ${ }^{39}$ By the time of the London House meeting Robinson noted that it seemed to be the opinion of all that definite cooperation

36 DP: 'War' Box 14: Lang to Davidson, 11 Dec 1915.

37 DP: 'War' Box 14: Temple to Davidson, 7 Feb 1916.

38 RP: Notes of Beaconsfield Meeting, additional memo.

39 RP: Trevelyan to Robinson, 6 Oct 1915. 
(with other religious bodies) would not be desirable or possible and practicable'. 40 Murray was prepared to justify this in terms of the conception of the Mission itself: he said at Beaconsfield that the national character of the Church of England was of the esse of the Church. Referring to Figgis and Maurice he spoke of the need to tell the nation of its corporate redemption in Christ: this was what distinguished the church's message from that of nonconformists, which centred on individual redemption. Evangelical Anglicans, however, saw the matter differently, and the announcement of the National Mission coincided with a decision by the London Evangelical Campaign to invite the American evangelistic team of Chapman and Alexander to London in the spring of 1916 (an invitation which they declined). Davidson had to write letters to Prebendary Webb-Peploe of the L.E.C. explaining that the National Mission would not be interdenominational, and he also had to reassure anxious anglo-catholics that it would not be like the London Evangelistic Campaign. Temple wrote to Davidson saying that it was vital that the Mission must be an effort of the Church of England:

but only less vital does it seem that people generally should regard it as an advance by the different sections of the Church in concert. I see only one way to arrange this. It is that privately the Free Church leaders should be informed of what is contemplated and told that while we think any movements must be initiated by the different bodies themselves, cooperation between parallel movements will be welcomed from our side to the very utmost possible degree. ${ }^{41}$ This was the solution Davidson adopted in February 1916 when he wrote to Cardinal Bourne and the Free Church Council before the official announcement to Convocation. This course of action did not prevent evangelical disappointment, however, and J. $\mathrm{H}$. Shakespeare, President of the Free Church Council, told Davidson in a private interview at Lambeth that the adjective 'national' in the title of the Mission 'had repeatedly been taken hold of . . . as implying claim on our side to be coextensive with the Nation'. ${ }^{42}$ At a conference of nonconformist and Anglican leaders at Lambeth in July, Shakespeare and others expressed the prayerful support of

40 RP: Report of a Conference, November 24, p 4.

4t DP: 'National Mission' Box 2: Temple to Davidson, 17 Dec 1915.

42 DP: 'War' Box 14: Memo of interview with Shakespeare, 23 Mar 1916. 


\section{War, the Nation, and the Kingdom of God}

the free churches for the Mission, and said they would make their own effort after the war. ${ }^{43}$ It is ironic that they chose the time originally envisaged by the Church of England, though in the event nothing was done. Despite the official policy, however, the National Mission can be seen as the occasion of the beginning of friendlier relations between Anglican and nonconformist leaders, which made the Lambeth conversations after 1920 possible.

The object of the National Mission, said the bishop of London, in a statement in March 1916, is that all shall know the Lord from the least to the greatest. If achieved this would solve our national problems-'the inequalities in our social system, the want of brotherhood between man and man, the tyranny of drink and lust, the misunderstandings between men and women'. ${ }^{44}$ Temple also believed that the message went to the individual-but 'to the individual first and foremost as a citizen ... There is a real difference between a converted nation and a nation of converted individuals. ' 45 The difference between these two positions, which at first sound so much alike, explains why Winnington-Ingram could not really lead the campaign proposed at Beaconsfield. In the same statement he quoted an Oxford undergraduate who had written to him from the trenches saying that war is a great purge.

There was also a third view:

I profoundly disbelieve in the possibility of any good coming of war (wrote Peter Green), and I regard all talk about war in itself being a moral purge, and a wholesome discipline, and a school of character, and all the rest of it, as being either profoundly immoral and antiChristian, or mere moral platitudes. ${ }^{46}$

This in turn indicates that Peter Green's scepticism about the National Mission went deeper than his belief that the influence of the clergy was nil and religious revival of the war had been exaggerated. Not only was he poles apart from WinningtonIngram; he could not really share the view of war, the nation and the kingdom of God that characterised a man like Temple. In the same essay Green wrote

Merely social and political work is not what is wanted of the

43 DP: 'National Mission' Box 1: Notes of Conference, 21 July 1916.

44 Church Times 3 Mar 1916, p 219.

${ }^{45}$ Temple, $A$ Challenge $\mathrm{p} 7$.

${ }^{46}$ Peter Green, 'The Humiliation of War' in G. K. A. Bell, ed The War and the Kingdom of God (London 1916) p 60. 
Church, or of its officers the clergy, or even of its members qua Churchmen. The remodelling of our industrial system may or may not be desirable, and may or may not be practicable . . But whether practicable and desirable or not, I am sure it is no part of the Church's duty to work for or to advocate such a change . . . it is the spirit of Brotherhood which the Church should labour to produce. ${ }^{47}$

But Green was not like Henson, who regarded the Mission as a blunder because it gave 'sudden, and wholly unmerited importance' to 'a number of foolish persons, ardent, bigotted, and ill-informed, who would not otherwise have gained a hearing'.48 He was not even like Conrad Noel who thought that the Mission was a confidence trick to give the impression of a social concern that was not there. Noel was wrong: the concern of men like Temple and Kempthorne, bishop of Lichfield, who expressed his anxiety to Davidson that 'the social aspects of a National Mission were not adequately emphasised'49, was genuine enough. Green's critique of the church in the first world war was more fundamental than most. He believed the root failure was a failure to put into practice the teaching of the sermon on the mount on non-resistance and evangelical poverty. The saying 'resist not evil' implied that no physical force can ever effect moral results, and that where material things were concerned, the Christian was called to suffer himself. Green was not a pacifist. He believed that England had been morally bound to declare war in 1914, but he believed that war was always morally wrong. England had lost the power to act rightly, and that was why repentance was necessary. He ran his great mission in Salford in 1926, ten years after the National Mission. ${ }^{50}$ Perhaps he was the only one of the twelve who stuck to the original vision: careful preparation, rooted in prayer, and after the war. All that was lacking was the emphasis on the nation, but perhaps during the war more weight had been placed on that than it could ultimately bear.

Fitzwilliam College, Cambridge

47 Ibid pp 91-2.

48 Braley, Letters p 15

49 DP: 'National Mission' Box 2: bishop of Lichfield to Davidson, 11 Feb 1916.

so Sheen, Peter Green pp 98-108. 